\title{
The Use and Abuse of Human Rights in International Relations. a case of the United States Foreign Interventions.
}

\author{
Kabelo Phofong Phamotse ${ }^{1}$, Wang Yonghui ${ }^{1}$, Zhang Xian ${ }^{1}$ \\ ${ }^{I}$ School of Politics and International Studies, Central China Normal University. \\ Wuhan city, Hubei Province, P R China.
}

\begin{abstract}
Human rights can be referred to as the rights which all human beings are entitled to just because they are human; the basis for these is a dignified existence for all, these rights have been provided for by the United Nations Universal Declaration of Human Rights. They are considered to be inherent rights regardless of race, colour, sex, nationality, status or any other form of classification that can be distinguish. However, human rights are sometimes viewed as, or misconstrued to be Western values, due to their leading role in enforcing human right tenets. The position of the West continues to be elevated at the expense of other states (For purposes of this paper the United States). There has been a lot of harm done in the name of human rights protection by some states against others in the international arena that some people have become sceptical of the proponents of human rights and for that matter other activities pursued in its name have been regarded as a mere pursuance of selfish interests. Hence, this article focused on increased violation of the rights of citizens of these vulnerable nations and how such actions threatening western nations as well.
\end{abstract}

Key words: Human right, Abuse, International Relations.

\section{INTRODUCTION}

Human rights are in their raw intentions noble values that are intended to observe, respect, preserve and retain people's integrity, their right to life and freedom to associate (or dissociate) without fear of discrimination, recrimination and reprisals when exercising such rights. It is therefore a default reaction for nation states to accept human rights watch bodies whose aim is to ensure that all people are accorded the humane treatment as prescribed and expected by the United Nations bodies handling human rights issues. Human rights issues and oversight bodies have however, fallen prey of super powers pushing personal agendas as and when it suits them thereby yielding negative results to those they were originally formulated to achieve. Originally, different nation states believed that other states can look into activities in other states to ensure observance of acceptable and agreed human rights principles whilst observing the sovereignty of member states. Therefore in 1946 the United Nations Commission for Human Rights was established and the Universal Declaration of Human Rights was adopted in 1948 by the United Nations. Decolonisation of Africa in the main and human rights issues that were predominant in other states such as South Africa's apartheid system resulted in intensified activity against the perceived oppressors and perhaps more interference in countries' internal activities. This brought in the era of political interventions and the United States (a super power) was one of the most vocal members in the advent of war crimes in states such as Iraq. The use and abuse of Human Rights looking specifically at the way the super powers such as the ways the United States of America has used this concept or ideology to attain its foreign policy goals in the economic, security, political and geo-strategic frameworks. This has come to light due to the fact that it is becoming more and more difficult for Western powers to hide their foreign policy agendas behind human rights as the motivator of their actions. And the rhetoric is growing to an extent that they use soft powerinfluence to get states to adopt ideologies that can later be used for the geopolitical and strategic motivations in making policies that cater for the future of their own goals. The United States in particular had used this as an excuse after the 9/11 attacks; launching a War On Terror. The Human Rights Bible, that is, the rule book, or basic guidelines to Human Rights are provided to us by the Universal Declaration of Human Rights (UDHR) adopted by the United Nations General Assembly in 1948; which indicates four main ideas that epitomise Human Rights as dignity, equality, freedom and justice (Amnesty International, 2016). These fundamentals are the scope through which the world can achieve an amicable co-existence between nations and attain universal world peace. The same idea is also reflected in the works of John Stuart Mill in his book entitled On Liberty. In this book he argues that a person does not have to explain themselves in any way when the actions done by them only affect the person making the choice alone; that is, the right to choice as long as it does not violate or infringe on anyone else's human rights (Mill 1859: 52). In addition to this, he expresses the limitation that, if the actions hurt any other person then the inflictor of the pain is liable to punishment for infringing on the other person's right to leisure, peace of mind and security (Mill 1859: 86). So, the argument here is that all peoples are 
entitled to exercise their rights, however, it must not be at the expense of others. Even though this is the case, he does see some actions that hurt others as necessary harms; for example: when a person gets to attain a job in a competitive job market, someone else who would have liked the job does not get it, thereby, hurting the other person but he (Mill) sees this as a general social good, the effect of this is positive, hence, such actions does not deserve punishment and there is no right to punish anyone for the harm caused (Mill 1859: 90). In essence, it breeds healthy competition for the other individual to better themselves and find creative means of securing an income.The significance of the emergence of Human rights was due to the atrocities that were committed during the Second World War (WWII); states committed numerous infringements to human rights; the right to life, being tortured etc.. and thus, human rights came about as a way to control individuals and states conduct(Facing History and Ourselves 2016). Giving birth to numerous International bodies such as United Nations Human Rights Commission, International Criminal Court, Amnesty International etc. Throughout history we have seen the US benefited from wars; how it has pushed forward its foreign policy agendas. Using its influence and support to allies to help them get a boost to win in WWII ending with the Hiroshima and Nagasaki, that is the US uses the Human rights policies as an instrument through which the politics of the world hegemony and foreign policy were advanced (Facing History and Ourselves 2016). We saw this in Panama, Burma, North Korea, Iraq, Libya, Syria etc. This is where we see the extent to which human rights discourse clearly became visible to rhetorical abuse in foreign policy, using the U S invasion situations in some of these nations as a case study. Human Rights are a concept with emotional appeal and the lack of conceptual clarity makes them immensely effective as a rhetorical tool and easily abused (Chandler 2009: 115). Here, the perception of what is real and what is not becomes key as to protect the concept of Human Rights; as failure to do so results in a debate of use/ misuse for selfish reasons. Trying to see human rights as universal, and its use in political rhetoric, actually prevents rather than fostering respect for human rights internationally (Chandler 2003). Further, when human Rights are used as a political rhetoric they lose their potential to be seen as a standard against which political action or inaction could be measured (Chandler 2003). In this article, focus is placed on the backdrop of proving that, the theory of Human Rights are being wrongly used by the Western states particularly the US as a tool to push their state agendas. Thus, supporting the notion of Chandler about the Western interests being confused as universal human rights values (Chandler 2009: 113). However, the use of Human Rights as a way to attain strategic political goals has led to a much deeper scrutiny of the actors voicing the infringement of Human Rights, questions are about who seeks to benefit from this? Why and How? A policy that has been drafted on the basis of Human Rights tends to be difficult to disclaim as Human Rights hold a large bearing.

\subsection{The US Foreign Policy and its Consequences on other Nations' Human Rights}

The US sees itself as the "Global Protector of Human Rights" and spearheads most or holds a position of power in most of the International Organisations that relate to human rights. According to the Human Rights Watch website (2016) the view on US foreign policy is quoted as follows "Human Rights Watch advocates for a US foreign policy that is consistent with its international human rights obligations". The US government should integrate human rights into its wider foreign policy agenda, engage regularly with independent civil society abroad, and work closely with allied governments to promote and protect human rights where they are most at risk. Influencing US foreign policy, whether directly with other governments or in intergovernmental organizations, is an essential tool to address, highlight, and promote human rights globally". The legality of humanitarian intervention is under discourse; Chapter VII of the UN Charter on the authorisation of the use of force by the Security Council with military force of one state or another is based on the fact that it will be an act of self- defence but humanitarian intervention does not fit this bill. Humanitarian intervention thereby falls into a grey area especially because there is no resolution by the Security Council that mandates it, it is not a measure of collective security (Hurd 2011).

\subsection{Realism in action Case Studys}

The US has always used Human rights violation as an excuse to go ahead and launch war to other nations whose social political policies and ideology did not align with those of the western countries. This was first seen when the US invaded Vietnam, and later a few other countries and the following are a few examples of how the US has pushed its agendas forward. This follows the believe of realist pessimists' that conflict is a norm when there is no higher power to resolve disputes and impose order. These examples will also show how the implications of framing Western human rights discourse as universal often result and are used to push its agendas.

2.1.2 The Iraq Invasion and its related consequences on Human Right.

Saddam Hussein was in power for over twenty years, that is from 1979 to 2003 when he was captured by the US special forces. Over the course of this twenty plus years, why had there been no intervention? Had the violations then been deemed necessary? No. At the time there was nothing to gain in the disruption of the system that was 
in place. In these years he used his secret police to terrorise the public and to suppress them thereby violating and ignoring Human Rights Laws (History 2016). He was then held captive and then tried for his crimes against humanity and sentenced to death by hanging in 2006 (The New York Times 2006). In 2003 invasion of Iraq which lasted from 20 March to 1 May 2003 and signalled the start of the Iraq War, which was code named Operation Iraqi Freedom by the United States, the few weeks leading to the US invasion of Iraq saw the US launched a huge media campaign of how Saddam Hussein was not good for the Iraqi people and that he was violating human rights, they talked about how Saddam Hussein called out and killed hundreds of people from a community who tried to oppose his rule in Iraq, the main reason for the invasion was that, the Saddam's regime was believed to be in violation of the disarmament act and continuing to make weapons of mass destruction with ties to Al- Qaeda (Kurth 2006). The US president at the time, President George Bush, sold the idea of Saddam being unfit and oppressive to be a president having weapons of mass destruction and does not pay attention to Human rights in his country, so the US used Human Rights as a tool to extend its agenda in Iraq (Kurth 2006). To this day, the US forces left Iraq leaving a power and security vacuum for Islamic extremist to fill the gap. Hence, the Human Rights violations in Iraq are far worse now than before they invaded the country. In addition to this, we see how Forsythe (2004: 78) described the policies that where implemented in Iraq to be meant for the greater good of the Iraqi state, but we end up seeing how this is not completely true and was just a shadow used to creep in and create an apparent legitimate reason to violate the sovereignty of the Iraqi nation.

From the information above we learn that the violations of Human Rights had long been happening and still continue to happen, where was the US then? Where is it now? It is content, because it has achieved its goal, which is to gain access to the oil reserves in the country. Further, the claims the US used to invade Iraq regarding weapons of mass destruction have not been proven to this very day.

\subsubsection{The Libyan Invasion and its Related Consequences}

In 2011, the Middle East experienced a political revolution now famously known as the Arab spring. The Arab spring started in Tunisia and is now still going on in Yemen, Libya and Syria having taken the form of a civil war in all these countries; we see with in the Arab spring, countries that never experienced external interference solved their internal disputes and are already back on track and their economies and social political settings back to normal, and in some cases even better with their newly elected administrations (Amnesty International 2016). President Muommar Gaddafi came to power in 1969 by means of a military coup and once in office, his primary acts was to try and find a way to liberate his country from what he called "unfair economic legacy of foreign domination" which is benefiting from the country's oil reserves (Asser 2011). Just as was done to the then president of Iraq months leading to the US and NATO support air strike in Libya. NATO already labelled with a habitual use of intervention as a means of justification of its actions thereby tainting the legality of International affairs where Human Rights are concerned. The media was painted with propaganda of how President Gaddafi is the worst thing to ever happened to the Libyan people and the name Gaddafi was turned into a house Hold name with western experts' giving interviews of how bad Gaddafi was and how his regime did not adhere to the norms of Human rights and labelling him a dictator (Asser 2011). They talked about how Gaddafi was not developing, but considering all every part in Libya after the invasion, the entire nation has been deep into a civil war, leaving the country divided into three parts with three different warring fictions claiming to be the legitimate government. As all this goes on, the US and its allies have pulled out and no one is ever talking about Libya apart from some few rogue journalists (Britannica 2011). such invasion had had multiplier effects of Human Rights violations of citizens of Libya.

\subsubsection{The Syrian crisis and its consequences on Human Right.}

Syria is now the worst case scenario for human rights violation in the world, the US tried to go into Syria using Human rights violations as an excuse after president Al Assad suppressed the riots and rebellion by using nerve gas; the US and the west turned the media propaganda but Russia did not support the US attack on Damascus (Volkskrant 2012). The approach which the US adopted was restrained and this rendered peace talks with little to no effect (Volkskrant 2012). This restraint was characterised as support of rebels by the US while Assad was defensive trying to avoid an airstrike and this act of inaction prolonged the Syrian war because air support would have caused President Assad to take the negotiations to heart (Noviny 2013). The US trained and armed the rebels in order to fight the Al Assad's government but most of them turned out to be ISIS followers, and after the training they crossed back to Iraq, as for now Syria has the highest number of refugees in the world as well as over five armed groups fighting in the country (BBC News 2015). It then became apparent that there was no certainty as to who may have used the chemical weapons and it suited the US to point to the Assad regime as the violator and an excuse for a push for intervention which would be war supporting the terror (Noviny 2013).

2.1.5 Trade Sanctions and Related Consequences on Human Right 
The US always puts trade restrictions on countries who they feel are not aligned with their foreign policies this include Russia, Venezuela ,Cuba and Iran although right to Trade is one of the Human rights. The US has always used trade restrictions to keep rogue countries in check which makes human rights a tool for the Americans to extend their foreign policies (The Guardian 2015). These sanctions have in turn created alliances of convenience between these states like Cuba and Iran; Cuban government received financial support from Iran and Havana allowed Iran to use its borders to block US satellite signals (Suchliki 2015). After these restrictions countries like Venezuela cannot feed or support its citizens. Also Iran and Venezuela are allied with each other in Uranium production and development this relationship is a result of a rebellion after sanctions (Suchliki 2015) so indirectly US is pushing some rogue behaviours. Comparison of the Cyprus issue, Turkey took land but the US does not intervene as it has no interests (Cropsey 2015). Further there are some bias that applies to Israel, how can it be allowed to join the UN International Law committee with the gross Human Rights atrocities against it?, Where is the US and its sanctions in these cases?(Cropsey 2015).

\subsection{Cyprus and Turkey and Related Consequences}

Turkey invaded Cyprus in 1974 and this was for a long time a non-issue and of no interest to the US. The invasion that has led to the continued occupation of the northern part of the Island to date has not triggered any form of reaction to the US until the recent trip of Vice President Biden to the Island. In 2014 after Turkey embraced Islam, it lead to increased tensions between Turkey and the US (Cropsey 2015). This geographic position of Cyprus has led to the US to consider its otherwise docile stance of the long standing Island's plight of its conquered territory. The Turkish government is suddenly being viewed to embrace Islamism and terrorism by proxy. Also the fact that in 2009, there were discoveries of natural gas in the off shores of Cyprus and this has made the US to change its stance against Cyprus (Cropsey 2015). These discoveries reinforced political and security cooperation between the US and Cyprus. This is a more defining phenomena of the US and its selfish interests as the issue of the Turkish invasion is over 40 years old but the recent developments in the economic front by way of gas discoveries and the political stance of Turkey has made the US become a new ally of Cyprus and its reconsideration of the Turkish occupation of Cyprus.

\section{CONCLUSION}

It is in the best interest of the US to take on less responsibility as to not appear opportunistic or antagonise the other states within the international arena. As this can be seen to be a problem in future. Whenever it has a hand in issues, the seed of doubt that begs to ask whether humanitarian intervention still serves to protect human rights of fulfilling its interest comes in to mind. Also possibly a more domestic approach would be appreciated, that is, lead by example - the US should look within itself before going out into the world to solve human rights issues when it suffers from the same plight hidden behind bureaucratic red tape and national security issues.

[1] Amnesty International. 2016. Arab Spring Five Years On. Available at: https://www.amnesty.org/en/latest/campaigns/2016/01/arab-spring-five-years-on/. Access 28 June 2016

[2] Amnesty International. 2016. Human Rights Basics. Available at : http://www.amnestyusa.org/research/human-rights-basics. Access: 28 June 2016

[3] Asser, M. 2011. The Muammar Gaddafi story. Available at: http://www.bbc.com/news/world-africa12688033. Access 28 June 2016

[4] BBC News. 2015. Syrian President Bashar Al- Assad: Facing down rebellion. Available at: http://www.bbc.com/news/10338256. Access 28 June 2016

[5] Britannica. 2016. Libya Revolt 2011. Available at: https://www.britannica.com/event/Libya-Revolt-of2011. Access 28 June 2016

[6] Chandler, D. 2009. 'The Ideological use/misuse of Human Rights', in Human Rights: Politics and Practice. Oxford: Oxford University Press.

[7] Cropsey, S. 2015. US Policy and Strategic Relationships of Greece, Cyprus and Israel: Power Shifts In Eastern Mediterrenean. Hudson Institute

[8] Facing History and Ourselves. 2016. Available at : https://www.facinghistory.org/universal-declarationhuman-rights/introduction-universal-declaration-human-rights. Access: 28 June 2016

[9] Forsythe, D. P. 2004. 'U.S. Foreign Policy and human rights in an era of insecurity' in Wars on Terrorism and Iraq. New York, Routledge.

[10] Hancock, J. 2007. Human Rights and US Foreign Policy. London: Routledge

[11] History. 2016. Capture of Saddam Hussein. Available at: http://www.history.com/this-day-inhistory/saddam-hussein-captured. Access 29 June 2016 
[12] Hurd, I. 2011. Is Humanitarian Intervention Legal? The Rule of Law in an Incoherent world. Available at: http://faculty.wcas.northwestern.edu/ ihu355/Home_files/is\%20hi\%20legal.pdf. Access 28 June 2016

[13] Kurth, J. 2006. 'Humanitarian Intervention after Iraq: Legal Ideals vs. Military Realities'Mill, J.S. 1859. On Liberty. Canada: Batoche Books Limited.

[14] Noviny, H: 2013. Intervention in Syria would support terror. Available at:http://hnonline.sk/. Access 29 June 2016

[15] Suchliki, J. 2015. Iran's Love Affair with Castro's Cuba. Available at: http://www.capitolhillcubans.com/2015_03_22_archive.html. Access 28 June 2016

[16] The Guardian. 2015. Which Countries are still affected by US sanctions. Available at: https://www.theguardian.com/us-news/datablog/2015/jul/21/which-countries-still-affected-us-sanctions. Access 29 June 2016

[17] The New York Times. 2006. Saddam Hussein, Defiant Dictator Who Ruled Iraq With Violence and Fear, Dies. Available at: http://www.nytimes.com/2006/12/30/world/middleeast/30saddam.html?_r=0. Access: 29 June 2016

[18] United Nations. 2016. Universal Declaration of Human Rights. Available at: http://www.un.org/en/universal-declaration-human-rights/. Access 29 June 2016

[19] Volkskrant, D. 2012. Civil War Raging In Syria. Available at: http://archiv.eurotopics.net/en/home/debatten/links-2012-06_syria/. Access 29 June 2016 